Discussion Paper No. 06-056

\title{
Patent Protection, Market Uncertainty, and R\&D Investment
}

Dirk Czarnitzki and Andrew A. Toole

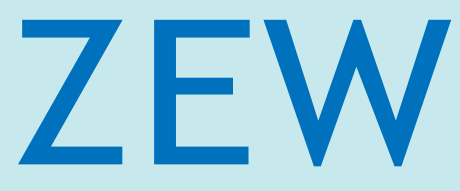

Zentrum für Europäische Wirtschaftsforschung $\mathrm{GmbH}$

Centre for European

Economic Research 
Discussion Paper No. 06-056

\title{
Patent Protection, Market Uncertainty, and R\&D Investment
}

\author{
Dirk Czarnitzki and Andrew A. Toole
}

Download this ZEW Discussion Paper from our ftp server:

ftp://ftp.zew.de/pub/zew-docs/dp/dp06056.pdf

Die Discussion Papers dienen einer möglichst schnellen Verbreitung von neueren Forschungsarbeiten des ZEW. Die Beiträge liegen in alleiniger Verantwortung der Autoren und stellen nicht notwendigerweise die Meinung des ZEW dar.

Discussion Papers are intended to make results of ZEW research promptly available to other economists in order to encourage discussion and suggestions for revisions. The authors are solely responsible for the contents which do not necessarily represent the opinion of the ZEW. 


\section{Non-technical Summary}

The main reason governments grant patent protection is to spur innovation. Patents give inventors temporary monopoly rights that allow them to appropriate a greater share of the returns from their innovations and this augments private incentives to undertake research and development (R\&D) investment. Consequently, patent protection should stimulate private R\&D investment.

Drawing on real options investment theory, this paper highlights one mechanism through which patents may improve appropriability and stimulate R\&D investment by reducing the effect of market uncertainty on the firm's investment decision. The real options framework predicts that greater uncertainty about market revenues reduces investment in irreversible capital by increasing the value of waiting.

A patent may protect the firm from market competition due to, among other things, imitation by rivals. This reduces the patenting firm's sensitivity to market uncertainty, decreases the value of waiting, and leads to greater current $R \& D$ investment. If patent protection mitigates market uncertainty, $R \& D$ investment by patenting firms should be less responsive to revenue volatility than non-patenting firms.

Our regression analysis tests this hypothesis. We find that R\&D investment by nonpatenting firms falls in response to market uncertainty measured by revenue volatility while firms with patent protection have no significant response. To date, this mechanism has not been examined in the literature but it may prove to be a fruitful approach to estimating the $R \& D$ incentive effects of patent protection, an indirect measure of the value of patenting. 


\title{
Patent Protection, Market Uncertainty, and R\&D Investment $^{1}$
}

\author{
by \\ Dirk Czarnitzki* and Andrew A. Toole** \\ May 2006
}

\begin{abstract}
The real options investment theory shows that greater uncertainty about market revenues reduces current $R \& D$ investment by increasing the value of waiting. This paper presents empirical evidence that patent protection mitigates the effect market uncertainty on R\&D investment.
\end{abstract}

Keywords: $\quad$ Real Options Theory, Uncertainty, R\&D, Intellectual Property Protection, Censored Regression

JEL Classification: O31, O33, C25

* Dirk Czarnitzki

Affiliation: $\quad$ KU Leuven, Belgium, and ZEW Mannheim, Germany

Mail address: Steunpunt O\&O Statistieken

Dekenstraat 2 3000 Leuven Belgium

Phone: $\quad$ +3216325 727

E-Mail: dirk.czarnitzki@econ.kuleuven.be
** Andrew A Toole

Rutgers University

Dept. of Ag, Food and Resource

Economics

55 Dudley Road

New Brunswick, NJ 08901

USA

+1 (732) 932-9155 ext. 215

toole@aesop.rutgers.edu

\footnotetext{
${ }^{1}$ We are grateful to the MIP team at ZEW Mannheim for providing the survey data.
} 


\section{Introduction}

The main reason governments grant patent protection is to spur innovation. Patents give inventors temporary monopoly rights that allow them to appropriate a greater share of the returns from their innovations and this augments private incentives to undertake research and development (R\&D) investment. ${ }^{2}$ Consequently, patent protection should stimulate private R\&D investment. However, the size of the R\&D stimulus from patent protection is far from clear since it depends on how effective patents are as a mechanism for appropriating returns. ${ }^{3}$

Drawing on real options investment theory, this paper highlights one mechanism through which patents may improve appropriability and stimulate R\&D investment - by reducing the effect of market uncertainty on the firm's investment decision. The real options framework predicts that greater uncertainty about market revenues reduces investment in irreversible capital by increasing the value of waiting (Pindyck 1991; Dixit 1992; Dixit and Pindyck 1994). R\&D investment is highlighted in this literature as a particularly relevant example of irreversible capital since a large proportion of $\mathrm{R} \& \mathrm{D}$ supports the salaries of research personnel and cannot be recouped if projects fail. Firms can avoid large losses by waiting for new information about market conditions and forgoing investment when this information is unfavorable. This would lower current R\&D investment. Alternatively, a patent may protect the firm from market competition due to, among other things, imitation by rivals. This

\footnotetext{
${ }^{2}$ Mazzoleni and Nelson (1998) discuss the various economic theories for patent protection and review some of the early empirical literature.

${ }^{3}$ This observation is the starting point for a large theoretical and empirical literature that cannot be summarized in this paper. The empirical literature uses either survey data or patent renewal data to shed light on differences in patent effectiveness or patent value. Also, since patenting involves the disclosure of information, the firm's decision to patent represents a tradeoff between monopoly rents and disclosure. Thus, patents do not unambiguously induce R\&D investment. Arora et al. (2003) discuss this issue and Cohen (2005) surveys the arguments and evidence on appropriation.
} 
reduces the patenting firm's sensitivity to market uncertainty, decreases the value of waiting, and leads to greater current $R \& D$ investment.

If patent protection mitigates market uncertainty, $R \& D$ investment by patenting firms should be less responsive to revenue volatility than non-patenting firms. Our regression analysis tests this hypothesis using an interaction term between revenue volatility and a dummy variable indicating whether the firm patents or not. We find that $R \& D$ investment by nonpatenting firms falls in response to revenue volatility while firms with patent protection have no significant response. To date, this mechanism has not been examined in the literature but it may prove to be a fruitful approach to estimating the $R \& D$ incentive effects of patent protection, an indirect measure of the value of patenting.

\section{Data}

Our sample is a pooled cross-section of 692 "innovative” manufacturing firms for 1998 and 2000 taken from the Mannheim Innovation Panel (MIP) survey. An innovative firm is defined to be a company that introduced at least one new product into a market during the previous six years, 1992-1997 and 1995-1999, respectively. In addition to the survey data, we collected information on the patenting activity from the German Patent and Trademark Office.

The dependent variable is $\mathrm{R} \& \mathrm{D}$ expenditure at the firm level $\left(R D_{i}\right)$ in millions of DM $(1.9583$ $\mathrm{DM}=1 \mathrm{EUR}$ ). Although we consider only previous product innovators, we find that about $29 \%$ of the firms in the sample did not conduct R\&D in 1998 or 2000 . Our econometric analysis takes this into account by modeling the censored distribution of R\&D. Above zero, the distribution of $R \& D$ spending is quite skewed and this motivates our logarithmic specification $\left(\ln R \& D_{i}\right)$. Since we cannot take the log of the censored observations at $R \& D_{i}=$ 
0 , we set those observations to the minimum observed positive $R \& D$ value in the sample and interpret this observed minimum as the censoring point in the regression models.

The covariate of central interest is market uncertainty (UNCER). We assume firms use their prior market experience as innovators to form their expectations about future market uncertainty. Market uncertainty is measured as the variance in the share of sales achieved with new products per year in the pre-sample period. The number of observations available for each firm varies from three to six years:

$$
U N C E R_{i}=\frac{1}{T_{i}} \sum_{t=1}^{T_{i}}\left(\operatorname{sales}_{i t}^{*}-\overline{\operatorname{sales}_{i}^{*}}\right)^{2},
$$

where sales $^{*}$ it denotes the share of sales achieved with new products in firm $i$ in year $t$. This variable captures the volatility of revenue from new market introductions.

Our analysis includes several firm level and aggregate level control variables. For each firm $i$ the variables are: (1) $D P A T_{t}$, a dummy variable identifying firms with patent protection in the pre-sample period; (2) PSTOCK ${ }_{t-1}$, the stock of firm patents to control for a firm's patent propensity; (3) $E M P_{t}$, the number of employees to control for firm size; (4) $C R_{t-1}$, credit rating index to control for the firm's access to credit markets (lower scores indicate better credit); (5) GROUP , a dummy varible to control for whether the firm is associated with a group of companies since these firms may have better access to capital; (6) FOREIGN dummy variable to control for subsidiaries of foreign companies. The aggregate level control variables include industry effects using eleven dummies variables; $H H_{t-1}$, the industry's Herfindahl index based on shares of market sales to control for the degree of competition; and a time dummy to control for other macroeconomic effects. Table 1 presents descriptive statistics of all variables used (for convenience the index $i$ indicating firm level variables is omitted). 
Table 1: Descriptive statistics (692 observations)

\begin{tabular}{lrrrr}
\hline Variable & Mean & Std. Dev. & Min & Max \\
\hline$R \& D_{t}$ (in million DM) & 15.483 & 117.155 & 0 & 1990 \\
$U_{N C E R_{t} \text { (uncertainty measure) }}$ & 0.054 & 0.072 & 0 & 0.500 \\
PSTOCK $_{t-1}$ (Patent stock) & 0.014 & 0.056 & 0 & 0.877 \\
EMP $_{t}$ (number of employees) & 899.270 & 3781.251 & 5 & 43118 \\
$H_{H}$ (industry concentration) & 45.779 & 66.090 & 3.441 & 427.702 \\
CR $_{t-1}$ (credit rating index) & 197.554 & 61.033 & 100 & 600 \\
$D_{2000_{t} \text { (year dummy) }}$ & 0.530 & 0.499 & 0 & 1 \\
GROUP $_{t}$ (group dummy) & 0.451 & 0.498 & 0 & 1 \\
FOREIGN $_{t}$ (foreign parent company) & 0.126 & 0.332 & 0 & 1 \\
\hline NOE: 11 ins
\end{tabular}

Note: 11 industry dummies not presented.

\section{Empirical Results}

Table 2 presents our regression results. We consider two versions of equation to be estimated: model A excludes the interaction between market uncertainty and patent protection in order to test the idea that market uncertainty reduces $R \& D$ investment; model $B$ includes the interaction to test our main hypothesis. We estimate both homoscedastic Tobit and heteroscedastic Tobit models. Likelihood ratio tests show that homoscedasticity is rejected.

As predicted by real options theory, model A shows that market uncertainty significantly reduces firm-level R\&D investment. This finding is consistent with prior work by Czarnitzki and Toole (2006) who find that market uncertainty reduces firm-level R\&D investment using a different sample and specification. ${ }^{4}$ It is also consistent with a larger body of empirical findings on how uncertainty effects physical capital investment. ${ }^{5}$

Model B allows the effect market uncertainty to differ across patenting and non-patenting firms and shows that $R \& D$ investment by patenting firms is less sensitive to revenue volatility than non-patenting firms. For non-patenting firms, market uncertainty significantly

\footnotetext{
${ }^{4}$ Using a sample of nine OECD countries, Goel and Ram (2001) find that "inflation uncertainty" reduces R\&D outlays.
} 
reduces $R \& D$ investment whereas for patenting firms the effect of market uncertainty is insignificant. ${ }^{6,7}$ Using the model, an increase in uncertainty by one standard deviation leads non-patenting firms to reduce $R \& D$ investment by $43 \%$, a sizable impact.

Schankerman (1998) suggests calculating the "equivalent subsidy to R\&D” (ESR) as measure of the private value of patent rights. ESR answers the question: "If patent protection were eliminated, what cash subsidy would have to be paid to firms performing R\&D to yield the same level of R\&D?” (Schankerman 1998, p. 95). Using the estimates from model B, we conduct a slightly different counter-factual exercise: if a non-patenting firm responded to uncertainty like a firm with patent protection, what is the implied increase in $R \& D$ investment? This exercise suggests that patent protection confers a $20 \%$ increase in $\mathrm{R} \& \mathrm{D}$ investment. While simple, our 20\% ESR estimate for German firms is consistent with the literature and falls between the Schankerman (1998) ESR estimate of 24.4\% using French data and the Arora et al. (2003) ESR estimate of 17\% using U.S. data. ${ }^{8}$

The control variables in the analysis have the expected signs although most are insignificant. Our results indicate that firm with a higher propensity invest more is R\&D. Firm size is also significant and indicates that larger firms invest more in R\&D.

\footnotetext{
${ }^{5}$ See Carruth et al. (2000) for a survey of these studies and Bulan (2004) for a recent contribution.

${ }^{6}$ Using OECD data, Kanwar and Evanson (2003) find that intellectual property rights significantly increase $\mathrm{R} \& \mathrm{D}$ investment as a share of gross national product.

${ }^{7}$ We tested for industry differences in the slope response to uncertainty. Using a Chi-squared test, we could not reject the null hypothesis of equality across the industry coefficients.

${ }^{8}$ Using patent renewal data, Lanjouw (1998) shows simulation results for four West German technology groups. Her ESR estimates range from $11.5 \%$ for engines to $75.4 \%$ for textiles.
} 
Table 2: Tobit regressions on $\ln (R \& D)$ at the firm level

\begin{tabular}{|c|c|c|c|c|}
\hline \multirow[t]{2}{*}{ Variable } & \multicolumn{2}{|c|}{ Model A } & \multicolumn{2}{|c|}{ Model B } \\
\hline & $\begin{array}{l}\text { homo- } \\
\text { scedastic }\end{array}$ & $\begin{array}{l}\text { hetero- } \\
\text { scedastic }^{\mathrm{a})}\end{array}$ & $\begin{array}{l}\text { homo- } \\
\text { scedastic }\end{array}$ & $\begin{array}{c}\text { hetero- } \\
\text { scedastic }{ }^{\text {a) }}\end{array}$ \\
\hline $\ln (E M P)$ & $\begin{array}{l}1.245 * * * \\
(0.093)\end{array}$ & $\begin{array}{l}1.392 * * * \\
(0.088)\end{array}$ & $\begin{array}{l}1.231 * * * \\
(0.094)\end{array}$ & $\begin{array}{l}1.378 * * * \\
(0.089)\end{array}$ \\
\hline UNCER & $\begin{array}{l}-7.953 * * * \\
(1.884)\end{array}$ & $\begin{array}{l}-8.300 * * * \\
(2.021)\end{array}$ & & \\
\hline$U N C E R^{*} D P A T$ & & & $\begin{array}{r}-4.786 \\
(3.402)\end{array}$ & $\begin{array}{r}-4.291 \\
(3.459)\end{array}$ \\
\hline$U N C E R^{*}(1-D P A T)$ & & & $\begin{array}{l}-8.919 * * * \\
(2.087)\end{array}$ & $\begin{array}{l}-9.798 * * * \\
(2.291)\end{array}$ \\
\hline PSTOCK/EMP & $\begin{array}{l}4.537 * * \\
(2.060)\end{array}$ & $\begin{array}{l}4.637 * * \\
(1.878)\end{array}$ & $\begin{array}{l}4.156 * * \\
(2.086)\end{array}$ & $\begin{array}{l}4.141 * * \\
(1.908)\end{array}$ \\
\hline $\ln (H H I)$ & $\begin{array}{r}0.150 \\
(0.151)\end{array}$ & $\begin{array}{r}0.170 \\
(0.145)\end{array}$ & $\begin{array}{r}0.141 \\
(0.151)\end{array}$ & $\begin{array}{r}0.172 \\
(0.145)\end{array}$ \\
\hline $\ln (C R)$ & $\begin{array}{r}-0.070 \\
(0.535)\end{array}$ & $\begin{array}{r}0.056 \\
(0.494)\end{array}$ & $\begin{array}{r}-0.104 \\
(0.535)\end{array}$ & $\begin{array}{r}-0.001 \\
(0.494)\end{array}$ \\
\hline D2000 & $\begin{array}{l}-1.520 * * * \\
(0.243)\end{array}$ & $\begin{array}{l}-1.353 * * * \\
(0.229)\end{array}$ & $\begin{array}{l}-1.436 * * * \\
(0.254)\end{array}$ & $\begin{array}{l}-1.238 * * * \\
(0.243)\end{array}$ \\
\hline GROUP & $\begin{array}{r}0.443 \\
(0.280)\end{array}$ & $\begin{array}{r}0.278 \\
(0.266)\end{array}$ & $\begin{array}{r}0.432 \\
(0.280)\end{array}$ & $\begin{array}{r}0.266 \\
(0.265)\end{array}$ \\
\hline FOREIGN & $\begin{array}{l}-0.307 \\
(0.380)\end{array}$ & $\begin{array}{r}-0.008 \\
(0.342)\end{array}$ & $\begin{array}{r}-0.303 \\
(0.379)\end{array}$ & $\begin{array}{l}-0.000 \\
(0.342)\end{array}$ \\
\hline Intercept & $\begin{array}{l}-11.374 * * * \\
(3.169)\end{array}$ & $\begin{array}{l}-16.213 * * * \\
(4.047)\end{array}$ & $\begin{array}{l}-11.112 * * * \\
(3.176)\end{array}$ & $\begin{array}{l}-15.888 * * * \\
(4.044)\end{array}$ \\
\hline $\begin{array}{l}\text { Test on joint significance of } 10 \\
\text { industry dummies }\left(\chi^{2}(10)\right)\end{array}$ & $103.47 * * *$ & $105.27 * * *$ & $103.17^{* * *}$ & $104.82^{* * *}$ \\
\hline \# of observations & 692 & 692 & 692 & 692 \\
\hline Log-likelihood & -1349.69 & -1315.56 & -1349.074 & -1314.56 \\
\hline McFadden $R^{2}$ & 0.145 & 0.167 & 0.145 & 0.167 \\
\hline $\begin{array}{l}\text { LR-test on heteroscedasticity } \\
\left(\chi^{2}(15)\right)\end{array}$ & & $68.26 * * *$ & & $64.58 * * *$ \\
\hline
\end{tabular}

Note: Standard errors in parentheses. *** (**, *) indicate a significance level of $1 \%(5,10 \%)$.

a) Heteroscedasticity term includes 10 industry dummies and 5 size dummies (based on the number of employees)

\section{Conclusions}

Drawing on the real options investment theory, this paper highlights one mechanism through which patent protection may improve appropriability and stimulate $R \& D$ investment: patent protection reduces the firm's sensitivity to market uncertainty, decreases the value of waiting, and leads to greater current R\&D investment. Our estimates suggest the ex post private value of patent rights for West German manufacturing firms in our sample is about 20\%. As with all exploratory work, our analysis leaves significant room for improvement and refinement. 
As richer data become available and more sophisticated methods can be applied, this "market uncertainty approach” to learning about the value of patent protection may be quite fruitful.

\section{References}

Arora, A., M. Ceccagnoli, and W.M. Cohen (2003), R\&D and the Patent Premuim, NBER Working Paper No. 9431, Cambridge, MA.

Bulan, L.T. (2005), Real Options, Irreversible Investment and Firm Uncertainty: New Evidence from U.S. Firms, Review of Financial Economics 14, 255-279.

Carruth, A., A. Dickerson and A. Henley (2000), What do we know about investment under uncertainty?, Journal of Economic Surveys 14(2), 119-153.

Cohen, W.M. (2005), Patents and Appropriation: Concerns and Evidence, Journal of Technology Transfer 30(1/2), 57-71.

Czarnitzki, D. and A.A. Toole (2006), Does market uncertainty reduce R\&D investments? A firm-level application of the real options theory, unpublished manuscript, KU Leuven and Rutgers University, NJ.

Dixit, A.K. (1992), Investment and Hysteresis, Journal of Economic Perspectives 6(1), 107132.

Dixit, A.K., and R.S. Pindyck (1994), Investment Under Uncertainty, Princeton University Press: Princeton, NJ.

Goel, R.K. and R. Ram (2001), Irreversibility of R\&D investment and the adverse effect of uncertainty: Evidence from the OECD countries, Economic Letters 71, 287-291.

Kanwar, S. and R. Evenson (2003), Does intellectual property protection spur technological change?, Oxford Economic Papers 55, 235-264.

Lanjouw, J.O. (1998), Patent Protection in the Shadow of Infringement: Simulation Estimations of Patent Value, Review of Economic Studies 65, 671-710.

Mazzoleni, R. and R.R. Nelson (1998), Economic Theories about the Benefits and Costs of Patents, Journal of Economic Issues 32(4), 1031-1052.

Pindyck, R.S. (1991), Irreversibility, Uncertainty, and Investment, Journal of Economic Literature 29(3), 110-1148.

Schankerman, M. (1998), How valuable is patent protection? Estimates by technology field, RAND Journal of Economics 29(1), 77-107. 